\title{
Antibacterial and Radical Scavenging Activity of Selected Orchids of Karnataka, India
}

\author{
Rashmi K ${ }^{1}$, Shweta S.D ${ }^{1}$, Sudeshna C.S ${ }^{1}$, Vrushala P.S ${ }^{1}$, Prashith Kekuda T.R ${ }^{1^{\star}}$ and \\ Raghavendra H.L ${ }^{2}$
}

\author{
${ }^{1}$ Department of Microbiology, S.R.N.M.N College of Applied Sciences, N.E.S Campus, Balraj Urs Road, \\ Shivamogga-01, Karnataka, India \\ ${ }^{2}$ College of Medical and Health Sciences, Wollega University, Post Box No: 395, Nekemte, Ethiopia
}

\begin{tabular}{|c|c|}
\hline Abstract & Article Information \\
\hline \multirow{4}{*}{$\begin{array}{l}\text { The present study was carried out to determine antibacterial and radical scavenging activity of } \\
\text { extract of four epiphytic orchids (Orchidaceae family) namely Luisia zeylanica Lindl., Pholidota } \\
\text { pallida Lindl., Dendrobium nutantiflorum A. D. Hawkes and A. H. Heller and Coelogyne } \\
\text { breviscapa Lindl collected at different places of Western Ghats of Karnataka, India. Antibacterial } \\
\text { and radical scavenging activity of orchid extracts was determined by Agar well diffusion and } \\
\text { DPPH free radical scavenging activity respectively. The total phenolic content was estimated by } \\
\text { Folin-Ciocalteau reagent method. All orchid extracts inhibited test bacteria. Marked antibacterial } \\
\text { activity was observed in case of C. breviscapa. Extract of L. zeylanica exhibited stronger radical } \\
\text { scavenging activity when compared to other orchid extracts. The phenolic content was highest } \\
\text { in L. zeylanica. A direct correlation was observed between phenolic content and radical } \\
\text { scavenging effect of orchid extracts. These orchids appear to be promising sources of bioactive } \\
\text { agents which can be exploited for treatment of several kinds of ailments. }\end{array}$} & $\begin{array}{ll}\text { Article History: } \\
\text { Received }: 11-01-2015 \\
\text { Revised }: 14-03-2015 \\
\text { Accepted }: 16-03-2015\end{array}$ \\
\hline & $\begin{array}{l}\text { Keywords: } \\
\text { Orchids } \\
\text { Agar well diffusion } \\
\text { DPPH } \\
\text { Total phenolic } \\
\end{array}$ \\
\hline & $\begin{array}{l}{ }^{*} \text { Corresponding Author: } \\
\text { Prashith Kekuda T.R } \\
\text { E-mail: }\end{array}$ \\
\hline & \\
\hline
\end{tabular}

\section{INTRODUCTION}

Orchidaceae is one of the largest families of the flowering plants with an estimate of $>800$ genera and $>25000$ species. The family Orchidaceae is a highly evolved and widely distributed family in monocotyledons of angiosperm. Orchids have diverse habits with variously modified floral parts. The orchids are represented by a large number of terrestrial, saprophytic and epiphytic species. They are distributed worldwide and exhibit incredible diversity in shape, size and color of the flowers. Orchids are important aesthetically, medicinally and are regarded as ecological indicators. They found economic uses especially in floriculture and hence many species of orchids are cultivated for ornamental purposes. Orchids have been used as food and in traditional medicine for treating several ailments by different cultures and tribes all over the world. Orchids are very sensitive to habitat degradation. Although large population of orchids is confined to their natural habitats, their number is decreasing because of high demand, habitat destruction and indiscriminate collection (Kumar et al., 2007; Maridass et al., 2008; Jalal and Jayanthi, 2012; Marasini and Joshi, 2012; Pant, 2013; Kiran et al., 2013; Sandrasagaran et al., 2014). Orchid extracts and purified compounds are shown to exhibit several bioactivities such as antimicrobial, antioxidant, anthelmintic, insecticidal, antiviral, analgesic, antipyretic, anti-allergic, wound healing, anti-aging, anticancer \& anti-inflammatory activity (Gutiérrez, 2010; Singh et al., 2012; Kiran et al., 2013).
The Indian subcontinent encompasses different climatic regimes, forest types and habitat conditions providing a favorable environment for accommodating diverse species. Next to Himalaya, the peninsular region of India has a high degree of endemism making it the second richest endemic centre (Jalal and Jayanthi, 2012). The Western Ghats is known to be one of the 34 biodiversity hotspots (also one among eight hottest hotspots of biodiversity) of the world. Western Ghats encompass a wide range of forest types ranging from tropical wet evergreen forests to grasslands and harbor rich flora and fauna evident from the occurrence of several species of flowering plants, butterflies, reptiles, birds, mammals, fishes and amphibians. The forests of Western Ghats are known to be a varietal storehouse of economically important plants. The tropical climate, heavy rainfall from southwest monsoon and favorable soil factors made the area ideal for the rich biodiversity. The Central Western Ghats area of Karnataka covers places viz., Kodagu, Hassan, Chikmagalur, Shivamogga, and Uttara Kannada (Ramachandra et al., 2013). In the present study, we have selected four epiphytic orchids namely Luisia zeylanica Lindl., Pholidota pallida Lindl., Dendrobium nutantiflorum A. D. Hawkes and A. H. Heller and Coelogyne breviscapa Lindl. collected from different places of Western Ghats of Karnataka, India. The present study was carried out in order to determine antibacterial and radical scavenging activity of selected orchids. 


\section{MATERIALS AND METHODS}

Collection and Identification of Orchids

The four epiphytic orchids (Table 1) of this study were collected from different places viz., Lakkavalli, Varadahalli and Seethalayyana Giri of Karnataka during January and
February 2015. The orchid specimens were authenticated by Prof. D. Rudrappa, Department of Botany, S.R.N.M.N College of Applied Sciences, Shivamogga-01, Karnataka. Voucher specimens were deposited in the department for future reference.

Table 1: Orchids selected for this study

\begin{tabular}{llll}
\hline \multicolumn{1}{c}{ Name } & \multicolumn{1}{c}{ Place of collection } & Habit & Part used \\
\hline L. zeylanica & Lakkavalli, Chikmagalur district & Herb, Epiphyte & Whole plant \\
P. pallida & Varadahalli, Shivamogga district & Herb, Epiphyte & Whole plant \\
D. nutantiflorum & Seethalayyana Giri, Chikmagalur district & Herb, Epiphyte & Whole plant \\
C. breviscapa & Seethalayyana Giri, Chikmagalur district & Herb, Epiphyte & Whole plant \\
\hline
\end{tabular}

\section{Extraction}

The orchids (whole plant material) were washed well using clean water and dried under shade. The shade dried materials were powdered in a blender. A known quantity of each of the powdered orchids (25g) was transferred into a separate conical flask and $100 \mathrm{ml}$ of ethyl alcohol (HiMedia, Mumbai) was added. The flaks were sealed and left for two days with occasional stirrings. Later, the content of each flask was filtered through 4-fold muslin cloth followed by Whatman No. 1 filter paper and filtrate was evaporated to dryness in order to get the extract (Dileep et al., 2014). The extracts were stored in refrigerator in amber colored containers.

\section{Antibacterial Activity of Extract of Selected Orchids}

Two Gram positive bacteria viz., Bacillus subtilis and B. coagulans and two Gram negative bacteria viz., Escherichia coli and Salmonella typhi were used. A loopful of each of the test bacteria were inoculated aseptically into test tubes containing sterile Nutrient broth (HiMedia, Mumbai). The tubes were incubated at $37^{\circ} \mathrm{C}$ for 24 hours. The broth cultures were used to assess their susceptibility to orchid extracts by Agar well diffusion assay. Using sterile cotton swabs, the broth cultures of test bacteria were inoculated on the surface of sterile Nutrient agar (HiMedia, Mumbai) plates by swabbing uniformly. With the help of a sterile cork borer, wells of $8 \mathrm{~mm}$ were punched in the inoculated plates. Extract of orchids $(20 \mathrm{mg} / \mathrm{ml}$ of $25 \%$ Dimethyl sulfoxide [DMSO; HiMedia, Mumbai]), reference standard (Chloramphenicol, $1 \mathrm{mg} / \mathrm{ml}$ of sterile water) and DMSO $(25 \%$, in sterile water) were transferred aseptically into respective wells. The plates were left for 30 minutes and then incubated at $37^{\circ} \mathrm{C}$ for 24 hours in upright position. The zones of inhibition formed around the wells were measured using a ruler (Pavithra et al., 2013).

\section{Radical Scavenging Activity of Extract of Selected Orchids}

The efficacy of orchid extracts to scavenge free radicals was tested by DPPH (1,1-diphenyl-2-picryl hydrazyl) radical scavenging assay. The extracts and DPPH were prepared in methanol. In brief, $1 \mathrm{ml}$ of each concentration of extract $(6.25-100 \mu \mathrm{g} / \mathrm{ml})$ was mixed with $3 \mathrm{ml}$ of DPPH solution $(0.004 \%$ in methanol) in separate tubes and incubated at room temperature in dark for 30 minutes. The absorbance was measured at $520 \mathrm{~nm}$. The absorbance of the DPPH control $(1 \mathrm{ml}$ methanol $+3 \mathrm{ml}$ DPPH solution) was noted. Ascorbic acid was used as reference standard. The scavenging effect $(\%)$ of each concentration of the extracts/ascorbic acid was calculated using the formula:

Scavenging activity $(\%)=[(\mathrm{Ac}-\mathrm{At}) / \mathrm{Ac}] \times 100$,

where Ac is absorbance of DPPH control and At is absorbance of DPPH and extract/standard combination (Pavithra et al., 2013). IC $\mathrm{C}_{50}$ (Inhibitory Concentration) value was calculated using Origin 6 software. The value represents the concentration of extract/standard required to scavenge $50 \%$ of free radicals.

\section{Total Phenolic Content (TPC) of Extract of Selected Orchids}

The TPC of orchid extracts was estimated by FolinCiocalteau reagent (FCR) method. Here, a dilute concentration of each orchid extract $(0.5 \mathrm{ml})$ was mixed with $0.5 \mathrm{ml}$ of $\mathrm{FC}$ reagent $(1: 1)$ and $2 \mathrm{ml}$ of sodium carbonate $(7 \%)$. The tubes were allowed to stand for 30 minutes at room temperature and the optical density was read at $765 \mathrm{~nm}$. A standard curve was plotted using different concentrations of Gallic acid (reference phenolic compound, $0-1000 \mu \mathrm{g} / \mathrm{ml}$ of sterile distilled water) and the TPC of orchid extracts was estimated. The TPC was expressed as $\mu \mathrm{g}$ Gallic acid equivalents (GAE) from the graph (Pavithra et al., 2013).

\section{RESULTS}

\section{Extract yield}

The yield of extract was $9.13 \%, 8.33 \%, 4.80 \%$ and $11.13 \%$ in case of $P$. pallida, $L$. zeylanica, $D$. nutantiflorum and $C$. breviscapa respectively.

\section{Antibacterial Activity of Orchid Extracts}

In the present study, it was observed that the extract of all orchids exhibited inhibitory effect against all test bacteria, but to a varied extent. Among orchids, marked antibacterial activity was displayed by $C$. breviscapa as indicated by wider zones of inhibition. Other orchids exhibited more or less similar inhibitory activity against test bacteria. Among Gram positive and Gram negative bacteria, $B$. subtilis and $E$. coli were inhibited to higher extent by extract of orchids respectively. Extracts were shown to inhibit $B$. coagulans and $S$. typhi to more or less similar extent. Reference antibiotic displayed marked inhibitory potential against test bacteria when compared to orchid extracts. Gram positive bacteria showed high susceptibility to antibiotic than Gram negative bacteria. DMSO did not show inhibition of test bacteria (Table 2). 
Table 2: Antibacterial activity of extract of selected orchids

\begin{tabular}{lcccc}
\hline \multirow{2}{*}{ Treatment } & \multicolumn{4}{c}{ Zone of inhibition in cm } \\
\cline { 2 - 5 } & B. coagulans & B. subtilis & S. typhi & E. coli \\
\hline L. zeylanica & 1.4 & 1.7 & 1.5 & 1.9 \\
D. nutantiflorum & 1.4 & 1.6 & 1.4 & 1.9 \\
P. pallida & 1.5 & 1.8 & 1.5 & 1.6 \\
C. breviscapa & 2.1 & 2.1 & 2.1 & 2.2 \\
Antibiotic & 3.8 & 3.9 & 3.6 & 3.6 \\
DMSO & 0.0 & 0.0 & 0.0 & 0.0 \\
\hline
\end{tabular}

\section{Radical Scavenging Ability of Orchid Extracts}

The result of scavenging of DPPH radicals by various concentrations of orchid extracts is shown in Figure 1. All orchid extracts displayed dose dependent scavenging of radicals i.e., on increasing the concentration of extract, scavenging efficacy was also increased. Highest and least scavenging potential was exhibited by extract of $L$. zeylanica and $P$. pallida respectively as revealed by $\mathrm{IC}_{50}$ values. The scavenging effect of orchid extracts is in the order- L. zeylanica $(62.62 \mu \mathrm{g} / \mathrm{ml})>C$. breviscapa $(71.91 \mu \mathrm{g} / \mathrm{ml})>D$. nutantiflorum $(91.46 \mu \mathrm{g} / \mathrm{ml})>P$. pallida $(128.31 \mu \mathrm{g} / \mathrm{ml})$. Reference antioxidant i.e., ascorbic acid displayed higher scavenging activity $(1.12 \mu \mathrm{g} / \mathrm{ml})$ when compared to orchid extracts.

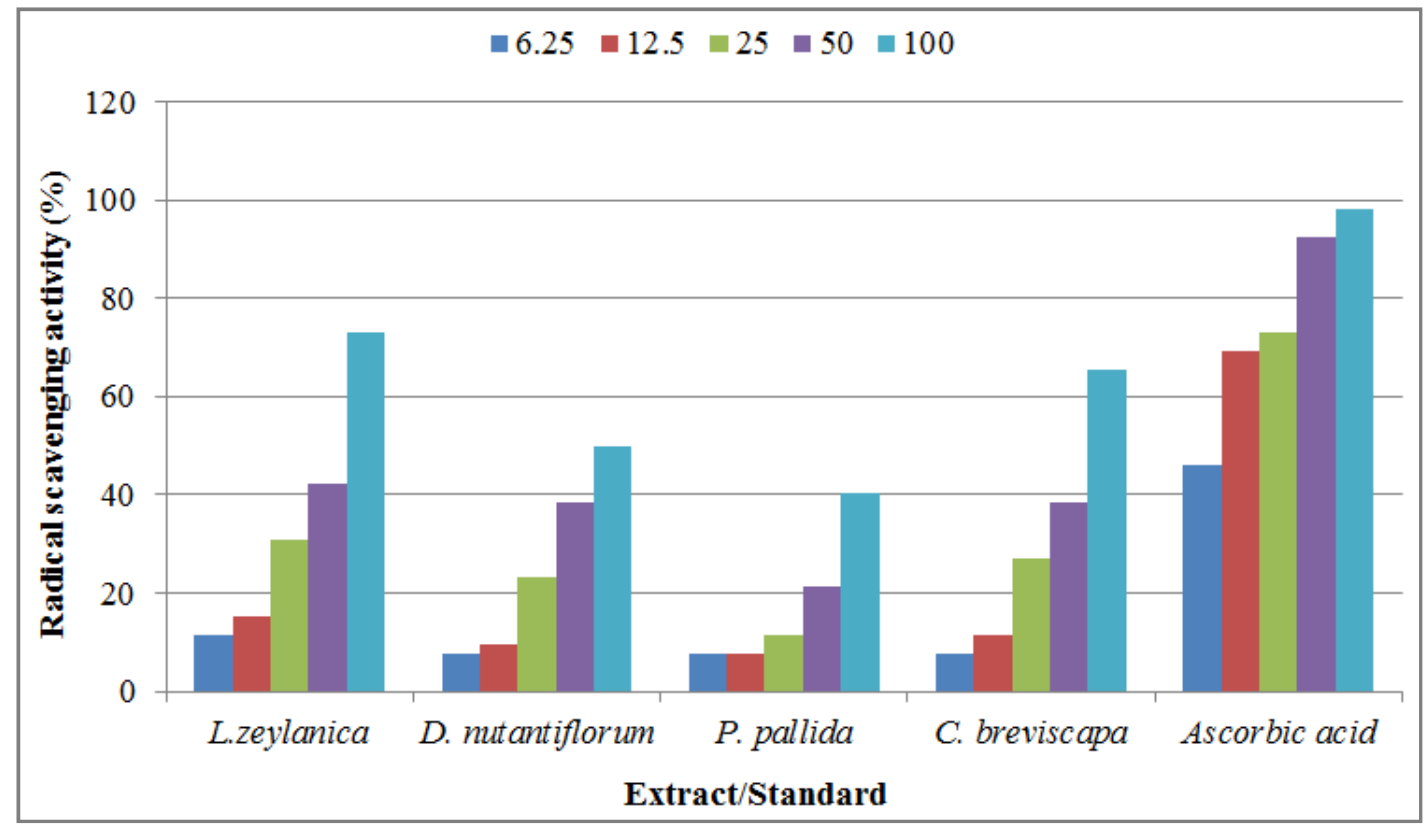

Figure 1: Radical scavenging activiyt of extract of selected orchids

\section{TPC of Extract of Selected Orchids}

The TPC, as estimated by FCR method, was expressed as mg GAE/g of extract. The TPC was found to be highest in extract of $L$. zeylanica $(43.66 \mathrm{mg} / \mathrm{g})$ followed by C. breviscapa $(25.00 \mathrm{mg} / \mathrm{g}), \quad D$. nutantiflorum (22.33mg/g) and P. pallida (12.33mg/g).

\section{DISCUSSION}

The discovery and subsequent use of antibiotics drastically reduced the morbidity and mortality caused by infectious agents. Perhaps, the use of these wonder drugs saved countless lives. However, the traditional antibacterial therapy using antibiotics faces problems such as high cost, side effects and the development of resistance in pathogens. Among these, the antibiotic resistance in pathogenic microorganisms is the most important one. Above all, the drug resistance can be inherited to susceptible population of bacteria which is a serious challenge for effective therapy. Hence, there is a great need for developing new antimicrobials from natural sources such as botanicals is increasing day by day
(Ojala et al., 2000; Hemaiswarya et al., 2008; Davies and Davies, 2010; Wright, 2010). Orchid extracts and their components were shown to exhibit antibacterial activity. In earlier studies, the species of Pholidota, Dendrobium and Coelogyne are shown to exhibit antibacterial activity (Marasini and Joshi, 2012; Sandrasagaran et al., 2014). In this study, Agar well diffusion assay was employed to determine antibacterial activity of extract of orchids selected. This assay is one of the most widely used in vitro antibacterial assays. The presence of zone of inhibition around the well was considered as positive for inhibitory activity and absence of inhibition zone was considered as lack of inhibitory activity. Among orchids, $C$. breviscapa exhibited stronger inhibitory activity against all test bacteria. Other orchid extracts inhibited test bacteria to more or less similar extent. It was observed that reference antibiotic exhibited stronger inhibitory activity when compared to orchid extracts. Antibiotic was found to inhibit Gram positive bacteria to higher extent when compared to Gram negative bacteria. However, in case of orchid extracts, such result was not observed. 
Free radicals are constantly produced during metabolism. However, excessive production of free radicals beyond the efficacy of antioxidant defense system of the body, leads to oxidative stress which is involved in causing more than one hundred disorders such as cancer, aging, cardiovascular and neurodegenerative diseases etc. The synthetic antioxidants have been suspected to cause negative health effects and hence, strong restrictions have been placed on their application. In recent years, much attention has been devoted to natural antioxidants in particular plants (Kekuda et al., 2011; Poornima et al., 2012). Many assays such as DPPH, ABTS and superoxide radical scavenging assay are used to screen in vitro radical scavenging activity of extracts. Among these, the DPPH scavenging assay is one of the widely used assays. DPPH is an organic, nitrogen centred, stable free radical having absorption maximum at $517 \mathrm{~nm}$ in alcoholic solution. DPPH becomes a stable diamagnetic molecule on accepting an electron or hydrogen atom. The compounds/extracts (antioxidants) having hydrogen donating potential can convert DPPH free radical (purple) into non-radical diphenylpicrylhydrazine (yellow). This $\mathrm{DPPH}$ assay is simple, sensitive and rapid assay for measuring the capacity of several types of samples including herbal extracts to scavenge free radicals (Chung et al., 2006; Poornima et al., 2012; Junaid et al., 2013; Kekuda et al., 2013). In the present study, we evaluated the radical scavenging potential of extract of selected orchids by DPPH assay. The extracts were effective in scavenging free radicals in a dose dependent manner. Among orchids, $L$. zeylanica exhibited stronger scavenging efficacy while $P$. pallida displayed low scavenging potential as indicated by $\mathrm{IC}_{50}$ values. The lower $I_{50}$ value indicate better scavenging activity. At $100 \mu \mathrm{g} / \mathrm{ml}$ concentration, a scavenging activity of $50 \%$ and higher was observed in case of extract of $L$. zeylanica, $D$. nutantiflorum and $C$. breviscapa. Reference antioxidant i.e., ascorbic acid scavenged DPPH radicals more efficiently than extracts. Though the scavenging efficacies of extracts were lesser than that of ascorbic acid, it is evident that the extracts showed hydrogen donating ability and therefore the extracts could serve as free radical scavengers, acting possibly as primary antioxidants (Chung et al., 2006). Orchids are shown to scavenge DPPH free radicals. Extracts from Dendrobium aqueum (Mukherjee et al., 2012), Coelogyne nervosa (Shibu et al., 2013) and Pholidota pallida (Nagananda et al., 2014) have shown to scavenge DPPH free radicals.

Polyphenolic compounds including flavonoids are among the most important metabolites possessing several bioactivities. These constituents are distributed in various parts of the plants like fruits, leaves, roots, seeds etc. Most bioactivities of phenolic compounds are due to their antioxidant nature. Hence, it is important to estimate the total phenolic contents of plant extracts in order to justify their possible contribution to antioxidant activity. In the present study, we estimated the TPC of orchid extracts by FCR method. The FCR method is one of the oldest and most widely employed methods used for estimating the TPC of plant extracts. The phenolic compounds react with FCR only under basic conditions (adjusted using sodium carbonate) and form blue complex having absorption maxima near $750 \mathrm{~nm}$. The assay is convenient, simple, and reproducible (Coruh et al., 2007; Kekuda et al., 2013). The phenolic content was highest and lowest in $L$. zeylanica and $P$. pallida respectively. In this study, a positive correlation was observed between the TPC and radical scavenging activity of orchid extracts i.e., extracts possessing high phenolic content exhibited marked scavenging of DPPH free radicals. Such correlations were observed in earlier studies (Tilak et al., 2004; Coruh et al., 2007; Kekuda et al., 2013).

\section{CONCLUSIONS}

In the present study, we evaluated antibacterial and radical scavenging effect of four epiphytic orchids collected from different regions of Western Ghats of Karnataka, India. The observed bioactivities of orchid extracts could be ascribed to the presence of phytochemicals, in particular phenolic compounds. The orchids can be used to prevent/treat infectious diseases and oxidative damage. Further studies on isolation of active principles from orchid extracts and their bioactivity determinations are to be carried out.

\section{Conflict of Interest}

All the authors declared no conflict of interest.

\section{Acknowledgements}

Authors are thankful to Head, Department of Microbiology and Principal, S.R.N.M.N College of Applied Sciences and N.E.S, Shivamogga for providing facilities and moral support to carry out work. Authors also thank Prof. D. Rudrappa, Lecturer and Head, Department of Botany, S.R.N.M.N College of Applied Sciences for helping in identification of plant materials.

\section{REFERENCES}

Chung, Y., Chien, C., Teng, K., Chou, S. (2006). Antioxidative and mutagenic properties of Zanthoxylum ailanthoides Sieb and zucc. Food Chemistry 97: 418-25.

Coruh, N., Celep, A.G.S., Ozgokce, F., Iscan, M. (2007). Antioxidant capacities of Gundelia tournefortii L. extracts and inhibition on glutathione-S-transferase activity. Food Chemistry 100: 1249-53.

Davies, J., Davies, D. (2010). Origins and evolutions of antibiotic resistance. Microbiology and Molecular Biology Reviews 74(3): 417-433.

Dileep, N., Rakesh, K.N., Junaid, S., Kekuda, P.T.R., Vinayaka, K.S., Raghavendra, H.L. (2014). Antibacterial and radical scavenging activity of selected plants of Western Ghats of Karnataka, India. Journal of Chemical and Pharmaceutical Sciences 7(2): 79-84.

Gutiérrez, R.M.P. (2010). Orchids: A review of uses in traditional medicine, its phytochemistry and pharmacology. Journal of Medicinal Plants Research 4(8): 592-638.

Hemaiswarya, S., Kruthiventi, A.K., Doble, M. (2008). Synergism between natural products and antibiotics against infectious diseases. Phytomedicine 15: 639-652.

Jalal, J.S., Jayanthi, J. (2012). Endemic orchids of peninsular India: a review. Journal of Threatened Taxa 4(15): 34153425.

Junaid, S., Rakesh, K.N., Dileep, N., Poornima, G., Kekuda, P.T.R., Mukunda, S. (2013). Total phenolic content and antioxidant activity of seed extract of Lagerstroemia speciosa L. Chemical Science Transactions 2(1): 75-80.

Kekuda, P.T.R., Manasa, M., Poornima, G., Abhipsa, V., Rekha, C., Upashe, S.P., Raghavendra, H.L. (2013). Antibacterial, cytotoxic and antioxidant potential of Vitex 
Rashmi et alo,

negundo var. negundo and Vitex negundo var purpurascens- A comparative study. Science Technology and Arts Research Journal 2(3): 59-68.

Kekuda, P.T.R., Vinayaka, K.S., Swathi, D., Suchitha, Y., Venugopal, T.M., Mallikarjun, N. (2011). Minera composition, total phenol content and antioxidant activity of a macrolichen Everniastrum cirrhatum (Fr.) Hale (Parmeliaceae). E-Journal of Chemistry 8(4): 1886-1894

Kiran, R., Kekuda, P.T.R., Kumar, P.H.G., Hosetti, B.B., Krishnaswamy, K. (2013). Biological activities of Sarcanthus pauciflorus. Journal of Applied Pharmaceutical Science 3(7): 105-110.

Kumar, P., Jalal, J.S., Rawat, G.S. (2007). Orchidaceae, Chotanagpur, state of Jharkhand, India. Check List 3(4): 297-304.

Marasini, R., Joshi S. (2012). Antibacterial and antifungal activity of medicinal orchids growing in Nepal. Journal of Nepal Chemical Society 29: 104-109.

Maridass, M., Hussain, Z.M.I., Raju, G. (2008). Phytochemical survey of orchids in the Tirunelveli Hills of South India. Ethnobotanical Leaflets 12: 705-712.

Mukherjee, S., Phatak, D., Parikh, J., Jagtap, S., Shaikh, S. Tupe, R. (2012). Antiglycation and antioxidant activity of a rare medicinal orchid Dendrobium aqueum Lindl. Medicinal Chemistry and Drug Discovery 2(2): 46-54.

Nagananda, G.S., Patil, A., Kambli, J.V., Rajath, S. (2014). Phytochemical Evaluation and in vitro Free Radical Scavenging Activity of Cold and Hot Successive Pseudobulb Extracts of Medicinally Important Orchid Pholidota pallida Lindl. Advances in Bioresearch 5(1): 100-105.

Ojala, T., Remes, S., Haansuu, P., Vuorela, H., Hiltunen, R., Haahtela, K., Vuorela, P. (2000). Antimicrobial activity of some coumarin containing herbal plants growing in Finland. Journal of Ethnopharmacology 73: 299-305.

Pant, B. (2013). Medicinal orchids and their uses: Tissue culture a potential alternative for conservation. African Journal of Plant Science 7(10): 448-476.
Sci. Technol. Arts Res. J., Jan-March 2015, 4(1): 160-164

Pavithra, G.M., Naik, A.S., Siddiqua, S., Vinayaka, K.S., Kekuda, P.T.R., Mukunda, S. (2013). Antioxidant and antibacterial activity of flowers of Calycopteris floribunda (Roxb.) Poiret, Humboldtia brunonis Wall and Kydia calycina Roxb. International Journal of Drug Development and Research 5(2): 301-310.

Poornima, G., Kekuda, P.T.R., Vinayaka, K.S. (2012). Antioxidant efficacy of Olea dioica Roxb (Oleaceae) leaves. Biomedicine 32(4): 506-510.

Ramachandra, T.V., SubashChandran, M.D., Bhat, S.P., Aithal, B.H., Rao, G.R., Mukri, V. Status of Forest in Shimoga District, Karnataka. ENVIS Technical Report 53. Energy and Wetlands Research Group, Centre for Ecological Sciences, Indian Institute of Science Bangalore 560012, India, May 2013.

Sandrasagaran, U.M., Subramaniam, S., Murugaiyah, V. (2014). New perspective of Dendrobium crumenatum orchid for antimicrobial activity against selected pathogenic bacteria. Pakistan Journal of Botany 46(2): 719-724.

Shibu, S.B., Devi, C.B., Moin, S., Wesley, S.P. (2013). Evaluation of bioactive potential of Coelogyne nervosa A.Rich. - An endemic medicinal orchid of Western Ghats, India. Asian Journal of Pharmaceutical and Clinical Research 6(S1): 114-118.

Singh, S., Singh, A.K., Kumar, S., Kumar, M., Pandey, P.K., Singh, M.C.K. (2012). Medicinal properties and uses of orchids: a concise review. Elixir Applied Botany 52: 11627-11634

Tilak, J.C., Adhikari, S., Devasagayam, T.P.A. (2004). Antioxidant properties of Plumbago zeylanica, and Indian medicinal plant and its active ingredient, plumbagin. Redox Report 9(4): 220-27.

Wright, G.D. (2010). QandA: Antibiotic resistance: where does it come from and what we can do about it? $B M C$ Biology 8: 123. 